\title{
EDITORIAL
}

\section{Stem Cell Blues}

\section{Kursad Turksen}

Published online: 5 June 2009

(C) Springer Science + Business Media 2009
"Ah... Keep your eyes on the road,

Your hands upon the wheel.

Gonna have a real good-time."

\section{Jim Morrison Doors,}

Roadhouse Blues, The Morrison Hotel (1970)

Reconciling the promises and potential of stem cells on the one hand, with the achievement of that potential in a clinical setting in some conceivable future on the other hand, is an enormous challenge. With the first two issues of Stem Cell Reviews and Reports now published, we are determined to cover important topics and exciting new data to help actualize the potential in the field.

With the tremendous speed with which the technologies and methodologies related to stem cells are growing, including recent developments in induced pluripotent cells, and the dramatic changes in the US political climate accompanying President Barack Obama's decision to lift the ban on embryonic stem cell research, it is a great period for stem cell research. With these rapidly moving changes, the goal of Stem Cell Reviews and Reports to cover not only original data and reviews in stem cell biology but also associated social, ethical and philosophical aspects of stem cell use, seems more timely than ever. My aim, with the help of a stellar editorial board, is to identify exciting contributions and challenging and emerging areas so as to provide an interesting platform for biologists, social scientists, lawyers, bioethicists and philosophers.

The conception of this new journal was over a dinner with Ray Colon in a Cuban restaurant in Manhattan more than a year ago and I am grateful to Ray for his commitment, dedication and personal support in appointing me Editor in Chief of a new journal.

It is also important to acknowledge the support and encouragements of Kathleen P. Lyons, Mindy OkuraMarszycki, Patricia Cleary, Patrick J. Marton, Tracy Catanese, and Vindra Dass, over the last year.

I am also very grateful to Lyda Cervantes for her fantastic efforts in the editorial office.

We are looking forward to many exciting submissions and related discussions.

"Gonna have a real good-time."

K. Turksen $(\bowtie)$

Sprott Centre for Stem Cell Research,

Ottawa Hospital Research Institute,

501 Smyth Road CCW \#5206E,

Ottawa, ON K1Y 8L6, Canada

e-mail: kturksen@ohri.ca 